\title{
Evaluation of Wood Resistance to Artificial Weathering Factors Using Compressive Properties
}

\section{Ocjena otpornosti drva na utjecaj umjetnih atmosferskih uvjeta mjerenjem tlačne čvrstoće}

\author{
Original scientific paper • Izvorni znanstveni rad \\ Received-prispjelo: 20. 2. 2015. \\ Accepted-prihvaćeno: 29. 1. 2016. \\ UDK: $630 * 812.72 ; 630 * 841.515$ \\ doi:10.5552/drind.2016.1355
}

\begin{abstract}
The purpose of the study was to determine the influence of artificial weathering on selected properties of wood. This paper presents the changes of incompressive strength of wood along fibers. The study involved wood of different density and anatomy - 17 species of tropical wood commercially available in Europe and Scots pine and European oak. The specimens were exposed to artificial weathering consisting of soaking wood in water, drying at $70{ }^{\circ} \mathrm{C}$ and exposure to UV radiation. Three-step aging cycle was repeated 140 times. In general, the tested wood species changed their compressive strength differently under the influence of artificial weathering. The process of artificial weathering caused a loss of strength of all tested wood species. The extent of changes depended on initial properties of wood (especially density) and anatomy. The changes were most pronounced at the beginning of the artificial weathering process.
\end{abstract}

Key words: tropical wood, Pinus, Quercus, artificial weathering, artificial aging

SAŽETAK • Cilj istraživanja bio je utvrditi utjecaj umjetnih atmosferskih uvjeta na promatrana svojstva drva. U radu je prikazana promjena tlačne čvrstoće drva uzduž vlakanaca. Istraživanje je provedeno na vrstama drva različite gustoće i anatomske građe - istraženo je 17 vrsta tropskog drva komercijalno dostupnoga u Europi te drvo običnog bora i europskog hrasta. Uzorci su bili izloženi umjetnim atmosferskim uvjetima: naizmjeničnom potapanju drva u vodi, sušenju na $70^{\circ} \mathrm{C}$ i izlaganju UV zračenju. Ciklus koji se sastojao od ta tri postupka ponovljen je 140 puta. Općenito, promjena tlačne čvrstoća drva pod utjecajem umjetnih atmosferskih uvjeta za istraživane je vrste drva različita. Izlaganje umjetnim atmosferskim uvjetima prouzročilo je smanjenje tlačne čvrstoće svih istraživanih vrsta drva. Opseg promjena nakon izlaganja povezan je s početnim svojstvima drva (posebno s gustoćom) $i$ anatomskom građom. Najveći intenzitet promjena zabilježen je na početku izlaganja umjetnim atmosferskim uvjetima.

Ključne riječi: tropsko drvo, Pinus, Quercus, umjetni atnosferski uvjeti, ubrzano starenje

\footnotetext{
${ }^{1}$ Authors are assistant professors at Warsaw University of Life Sciences - SGGW, Department of Wood Sciences and Wood Protection, Faculty of Wood Technology, Warsaw, Poland.

Autori su docenti Varšavskog sveučilišta bioloških znanosti - SGGW, Odjel znanosti o drvu i zaštite drva, Fakultet drvne tehnologije, Varšava, Poljska.
} 


\section{INTRODUCTION}

\section{UVOD}

The increasing demand for tropical wood products leads to expanded trade offers, and requires knowledge of the characteristics of exotic wood such as its physical, mechanical, technological properties and its resistance to external factors. Tropical wood species, having wide trunk diameters, attractive texture and high resistance to decay, are used in different industries e.g. furniture, timber, plywood, and outdoor applications such as garden furniture, fences, facades, terraces, etc. (Williams, 2005; Kilic and Niemz, 2012). The decisive element for the use of different wood species in the harsh outside environment is their durability. Natural durability of wood depends on work conditions (hazard classes and construction features), as well as on the type of wood. Variations of weather conditions and prolonged exposure to weathering elements cause the process called weathering.

Many researchers, involved in changes of wood properties caused by varying environmental conditions, describe the natural weathering of wood as a process of irreversible changes in the appearance and properties of a material as the effect of a long-term impact of weather: solar radiation, air and oxygen contained in it, changes in temperature and humidity, assuming no direct influence of biotic factors (Holz, 1981; Feist, 1990; Feistand Hon, 1984; Hon et al, 1986; Tolvaj and Faix, 1995; Colom et al, 2003; Williams, 1999, 2005). Wood weathering is a complex phenomenon (multifactorial) caused by solar radiation and by hydrolysis and leaching of wood components. Due to cyclical changes in humidity, swelling and shrinkage have a significant influence on changes in wood properties in the weathering process. Due to slowness and questionable repeatability of the process, it is difficult to examine wood weathering and its consequences. Substantial changes often appear in real terms after many years of using wood. For this reason, various methods of artificial weathering were developed in laboratories to simulate the natural effect of weather conditions and to determine changes occurring in wood in short time. These methods differ between themselves in order and intensity of effects of individual factors (eg. Temiz et al., 2007; Evans et al., 2008;
Follrich et al., 2011; Miklečić and Jirouš-Rajković, 2011). In addition, the fact should be taken into account that the size of samples used to determine the mechanical properties of artificially weathered wood is unrestricted, one published study - right for a type of test samples and artificial weathering - cannot be directly related to the results obtained in other trials.

Degradation phenomena have been reported in literature, e.g. Evans et al. (1996) studied the loss of mass and chemical changes occurring in wood Pinus radiata D. Don. during weathering. Evans et al. 2008, Bhat et al. (2010) tested wood and modified wood materials including its mechanical properties during weathering. Changes of physical properties were mainly tested (Oltean et al., 2009; Schnabel et al., 2009). Researches of tropical wood in this field are few. An example of the study of artificial weathering of tropical wood are tests made by Pastore et al.(2004) and Oltean et al. (2010) - change of appearance and color were tested.

In this paper, the effects of artificial weathering on compressive properties of several species of wood (assuming the absence of biotic interactions) were determined and compared to each other.The study includes seventeen species of wood from foreign forests (heartwood), commercially available in Europe. Parallel studies were performed on the control wood: pine Pinus sylvestris L. (individual sapwood and heartwood) and European oak Quercus sp. (heartwood). As the processs of weathering progressed, compression strength along fibers was determined.

\section{MATERIALS AND METHODS}

\section{MATERIJALI I METODE}

\subsection{Preparation of test specimens}

2.1. Priprema uzoraka

Wood species selected for the research (Table 1) are a group of materials used for production of elements used in external conditions (such as elevation, terrace boards, garden furniture, etc.). This wood group represents different types of structures (coniferous, deciduous ring-pours and diffuse-pours) and differs in some details related to anatomy and density (Figure 1).

Samples of each wood species were collected from one board to obtain "identical sample". Thanks to

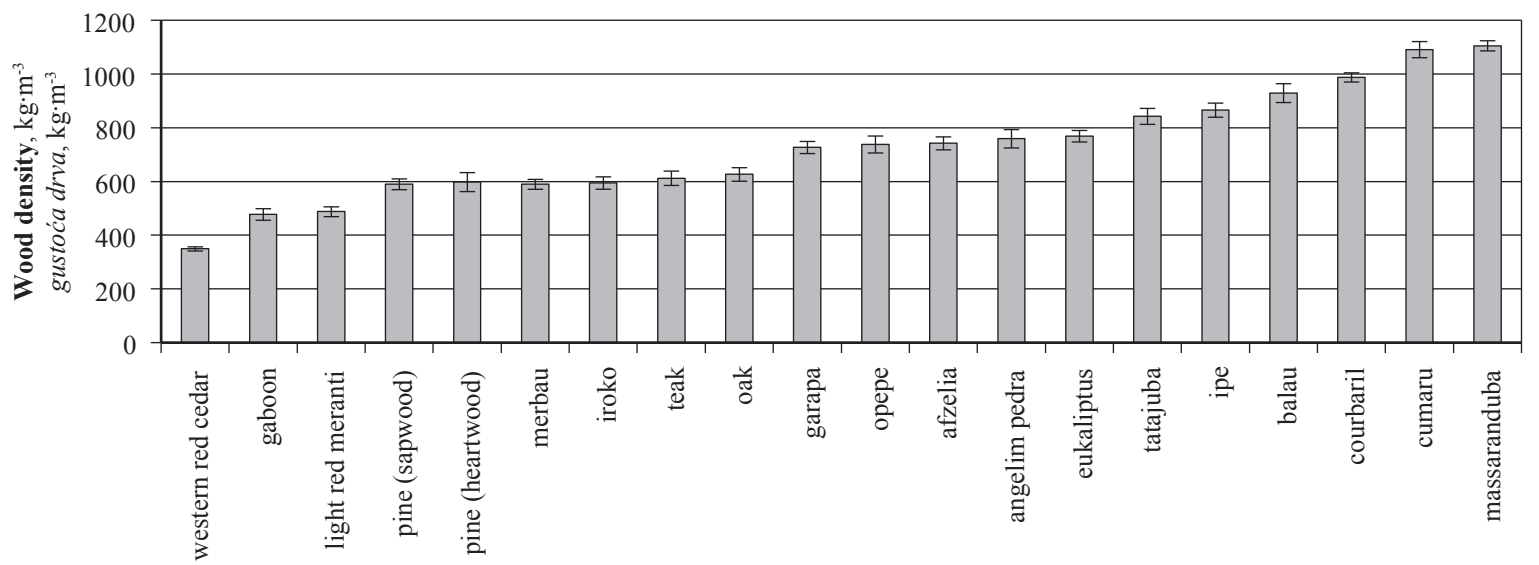

Figure 1 Comparison of average airdry wood density of species tested (for the whole batch of samples)

Slika 1. Usporedba prosječne gustoće uzoraka istraživanih vrsta drva (za cijelu seriju uzoraka) 
Table 1 Research material

Tablica 1. Istraživani uzorci drva

\begin{tabular}{|c|c|c|c|}
\hline Latin name / Latinski naziv & \begin{tabular}{|c|} 
Trade name and name \\
according to PN-EN \\
$\mathbf{1 3 5 5 6}$ (2005) / Trgovački \\
naziv i naziv prema \\
PN-EN 13556 (2005) \\
\end{tabular} & $\begin{array}{l}\text { Occurrence } \\
\text { Stanište }\end{array}$ & $\begin{array}{c}\text { Type of structure } \\
\text { Vrsta anatomske građe }\end{array}$ \\
\hline Afzelia africana Smith ex Pers. & afzelia & Africa & \multirow{12}{*}{$\begin{array}{l}\text { deciduous diffuse-pours } \\
\text { listopadna difuzno-porozna }\end{array}$} \\
\hline Apuleia leiocarpa (Vog.) Macbride & garapa* & South America & \\
\hline Aucoumea klaineana Pierre. & gaboon & Africa & \\
\hline Bagassa guianensis Aubl. & tatajuba & \multirow{2}{*}{ South America } & \\
\hline Dipteryx odorata (Aubl.) Wild. & cumaru & & \\
\hline Eucalyptus sp. & eucalyptus & Asia & \\
\hline Hymenea courbaril Linn. & courbaril & \multirow{2}{*}{ South America } & \\
\hline Hymenolobium sp. & angelim pedra & & \\
\hline Intsia bacori Prain. (Intsia bijunga Ktze.) & merbau & Asia & \\
\hline Manilkara bidentata A. Chev. & massaranduba & South America & \\
\hline Milicia excelsa (Welw.) C. C. Berg & iroko & \multirow{2}{*}{ Africa } & \\
\hline Nauclea diderrichii (Wild. \& Th. Dur.) Merr. & opepe & & \\
\hline Pinus sylvestris L. & Scots pine & \multirow[b]{2}{*}{ Europe } & coniferous / četinjača \\
\hline Quercus petraea Liebl., Q. robur L. & European oak & & $\begin{array}{l}\text { deciduous ring-pours } \\
\text { listopadna prstenasto-porozna }\end{array}$ \\
\hline Shorea sp., e.g. S. acuminate Dyer. & light red meranti & \multirow{2}{*}{ Asia } & \multirow{3}{*}{$\begin{array}{l}\text { deciduous diffuse-pours } \\
\text { listopadna difuzno-porozna }\end{array}$} \\
\hline Shorea sp., e.g.. S. laevis Ridley & balau & & \\
\hline Tabebuia sp. & ipe & South America & \\
\hline Tectona grandis $\mathrm{L}$. & teak & Asia & $\begin{array}{l}\text { deciduous ring-pours } \\
\text { listopadna prstenasto-porozna }\end{array}$ \\
\hline Thuja plicata D. Don & western red cedar & North America & Coniferous / četinjača \\
\hline
\end{tabular}

* Apuleia leiocarpa (Vog.) Macbride are not included in PN-EN 13556 (2005)

these samples, density was similar and the structure was kept in order to appearing changes in the weathering process, this being the main factor deciding on the examined properties. 30 groups of 6 samples were prepared from each wood species. Dimensions of samples were $15.0 \times 15.0 \times 22.5 \mathrm{~mm}$ (the last dimension along fibers). Each group was intended for the study of different stages of weathering. Before the determination of properties, each group was air conditioned at a temperature close to $20^{\circ} \mathrm{C}( \pm 2)$ and relative humidity $(\mathrm{rH})$ around $60 \%( \pm 5)$.

\subsection{Artificial weathering method}

\subsection{Izlaganje umjetnim atmosferskim uvjetima}

The design of the artificial weathering cycle was based on literature (Matejak et al., 1983: Follrich, 2011). It took 30 hours to complete an artificial weathering cycle and it was divided into three steps (Figure $2)$. The first step was soaking speciemens in water at 20 ${ }^{\circ} \mathrm{C}(16 \mathrm{~h})$. The conditions of the second step $(8 \mathrm{~h})$ were $70{ }^{\circ} \mathrm{C}$ and $5-10 \% \mathrm{rH}$ and the third step was performed at $30{ }^{\circ} \mathrm{C}$ and $20-25 \mathrm{rH}(6 \mathrm{~h})$ with irradiation with UV rays. Four fluorescent lamps100R's Lightech of $100 \mathrm{~W}$ each, and the spectrum $300-400 \mathrm{~nm}(90 \%$ of the radiation spectrum is a wavelength of $340-360 \mathrm{~nm}$ ) were used for irradiating. 140 cycles of artificial weathering were conducted.

\subsection{Mechanical testing}

\subsection{Određivanje tlačne čvrstoće}

Examination of compressive strength of wood along fibers was performed before weathering, and then

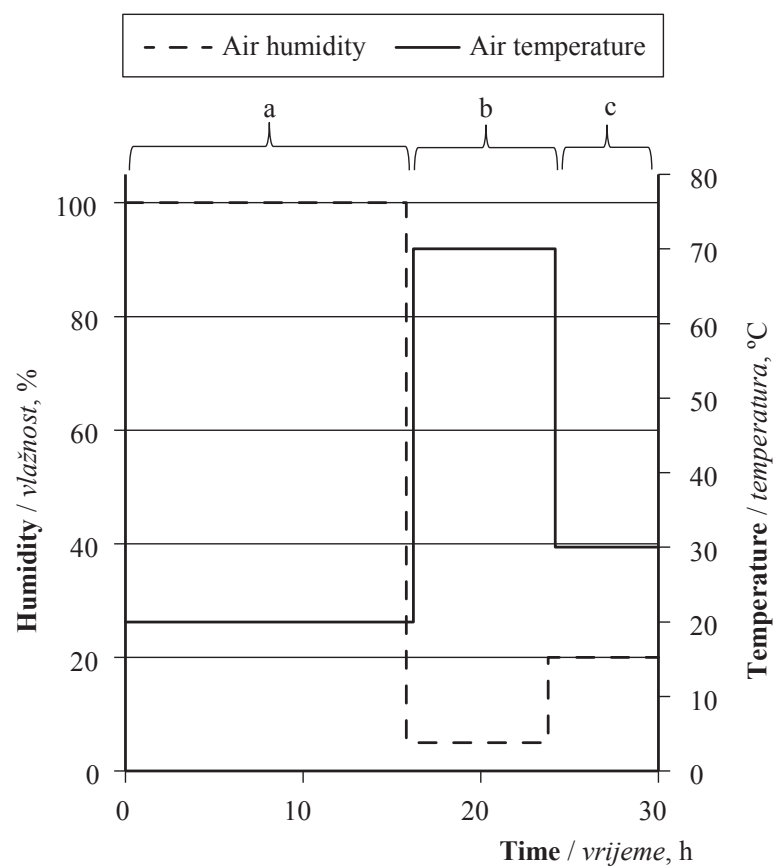

Figure 2 Changes in humidity and temperature during a full cycle of artificial weathering: a) soaking in water for 16 hours, b) drying at $70^{\circ} \mathrm{C}$ for $8 \mathrm{~h}, \mathrm{c}$ ) UV irradiation for 6 hours Slika 2. Promjene vlažnosti i temperature tijekom jednog ciklusa umjetnih atmosferskih uvjeta

after 2, 4, 6, 8, 10, 12, 14, 16, 20, 24, 28, 32, 36, 40, 44, $48,52,56,60,64,68,76,84,92,100,108,116,124,132$ and 140 cycles of artificial weathering. The compression test was performed according to PN-D 04102 (1979). 
The use of slightly smaller dimensions of samples was a deviation from the mentioned norm. The deviation concerning the sample size occurred in view of the fact that no relation exists between the compressive strength along fibers and the size of samples when they are geometrically similar and when the section of the samples contained at least a couple of annual increments (Matejak et al., 1983). The aim of this treatment was to cause great changes in wood during the aging process. Examination of compressive strength of wood along fibers $(R C)$ was carried out on the 10-ton universal testing machine. Constant speed of loading samples of $2 \mathrm{~mm} / \mathrm{min}$ was used during the compression tests. For individual groups of samples, average values as well as standard deviations were calculated.

In order to illustrate the effect of artificial weathering of wood, the approximate percentage of decrease of compressive strength along fibers per one cycle of artificial weathering was determined by the formula:

$$
\Delta R C=\left(R C_{0}-R C_{n}\right) \cdot\left(R C_{0} \cdot n\right)^{-1} \cdot 100
$$

where: $\triangle R C$ - percent decrease in compressive strength along fibers per one cycle of artificial weathering, $R C_{0}$ - compressive strength of wood along fibers before artificial weathering, $R C_{n}$ - compressive strength of wood along fibers after $n$ number of cycles of artificial weathering, $n$ - number of artificial weathering cycles.

\section{RESULTS AND DISCUSSION}

\section{REZULTATI I RASPRAVA}

The study shows that the compressive strength of wood along fibers was reduced due to the artificial weathering process. The same direction of changes was observed for every tested wood species. By analyzing the average values of compressive strength along fibers, it has been observed that gaboon showed the greatest changes. 140 cycles of artificial aging process caused the loss of strength c. $35 \%$ (from an initial value of $43 \mathrm{MPa}$ to the final $28 \mathrm{MPa}$ ). Merbau also showed a large change - the change of c. $33 \%$ occurred from $65 \mathrm{MPa}$ to $43 \mathrm{MPa}$. Teak showed the greatest resistance to weathering stated by the smallest change in compressive strength along fibers. Strength of wood was falling from the initial value of $58 \mathrm{MPa}$ to $48 \mathrm{MPa}$ (reduction c. $18 \%$ ). Massaranduba showed a similar range of changes of compressive strength due to aging factors. 140 cycles of artificial weathering caused a loss of the compressive strength along fibers from the initial value of $92 \mathrm{MPa}$ to $74 \mathrm{MPa}$ (reduction c. $20 \%$ ). European oak, Scots pine (sapwood and heartwood) showed the rate of change of compressive strength along fibers similar to opepe and garapa (about $28 \%$ ). There was no difference in strength loss between Scots pine sapwood and heartwood. Both of them (heartwood and sapwood) were made from one board, which was the material of similar properties (similar density). It is important to emphasize European coniferous wood species, because sapwood is an important and often dominant part of trunk volume.

Based on the results, it can be assumed that, due to aging, the loss of compressive strength of wood along fibers is mainly caused by changes in wood structure. Cyclical changes in humidity and temperature caused strong stress (sorption and thermal) exceeding internal cohesion of wood. It resulted in cracks and significant loss of wood strength. There was also a mass loss due to leaching of a number of extractives from the cell walls and partial hydrolysis of hemicellulose and cellulose (relaxed frame of ligno-cellulosic, the disintegration of some long-chain tissue constituents of wood) in subsurface layers, which consequently led to the reduction of wood density. The main cause of deterioration of mechanical properties lies in cyclical changes of moisture conditions, whicih causes tissue destruction of wood (wood cracks). Wood cracks are the consequence of sorption stresses, which occur during rapid wetting and quick drying (Matejak et al., 1983; Feist, 1983, 1990; Feist and Hon, 1984; Williams, 1999, 2005). High frequency of changes in humidity causes cracking of wood - the larger amplitude and changes of frequency, the larger the damage. The cumulative impact of wood weathering factors leads to the damage of a wood structure, which is reflected in changes of its initial mechanical properties.

It is hard to indicate one particular factor that affects the extent of loss of compressive strength along fibers of tested wood species. This is probably the interaction of many factors with many interactions between them - this is a submicroscopic construction of wood (cell walls), microscopic (size, layout and contribution of individual structural elements - rays, parenchyma, fibers, vessels), macroscopic (width and layout of annual growth, the share of earlywood and latewood) and its chemical composition (types of extractives - resins, tannins, oils, minerals and other).

Gaboon is a wood with tangled texture - wood shows variations of cross grain. Deviation of wood fibers from the direction parallel to the longitudinal axis of the trunk causes an additional loss of strength. The loss of strength rises with increasing slope and cracks. Similarly, merbau has an irregular arrangement of fibers. Any deviation from fiber direction parallel to the direction of the destructive force causes the loss of strength (slope of $15^{\circ}$ lowers the compressive strength of wood by $20 \%$ - Kollmann and Côte, 1968). Additionally, in the case of merbau, a relatively large content of extractives negatively affects the change of strength (Grabner et al., 2005).

The change of the compressive strength along fibers of garapa and opepe, similar to European wood species of much lower density (Figure 1), can also be explained by a cross grain. Both opepe and garapa wood are characterized by variations of deflected fibers. In the case of teak, the smallest change in strength can be explained by limited changes in wood moisture due to artificial weathering. Acting hydrophobically, oily substances limited alternating swelling and shrinking, after soaking in water and drying, which led to weakening of wood structure through desorption cracks. The presence of oils in cumaru had no effect on changes in strength. Cumaru, merbau, gaboon and opepe show a cross grain. The consequence of irregular 


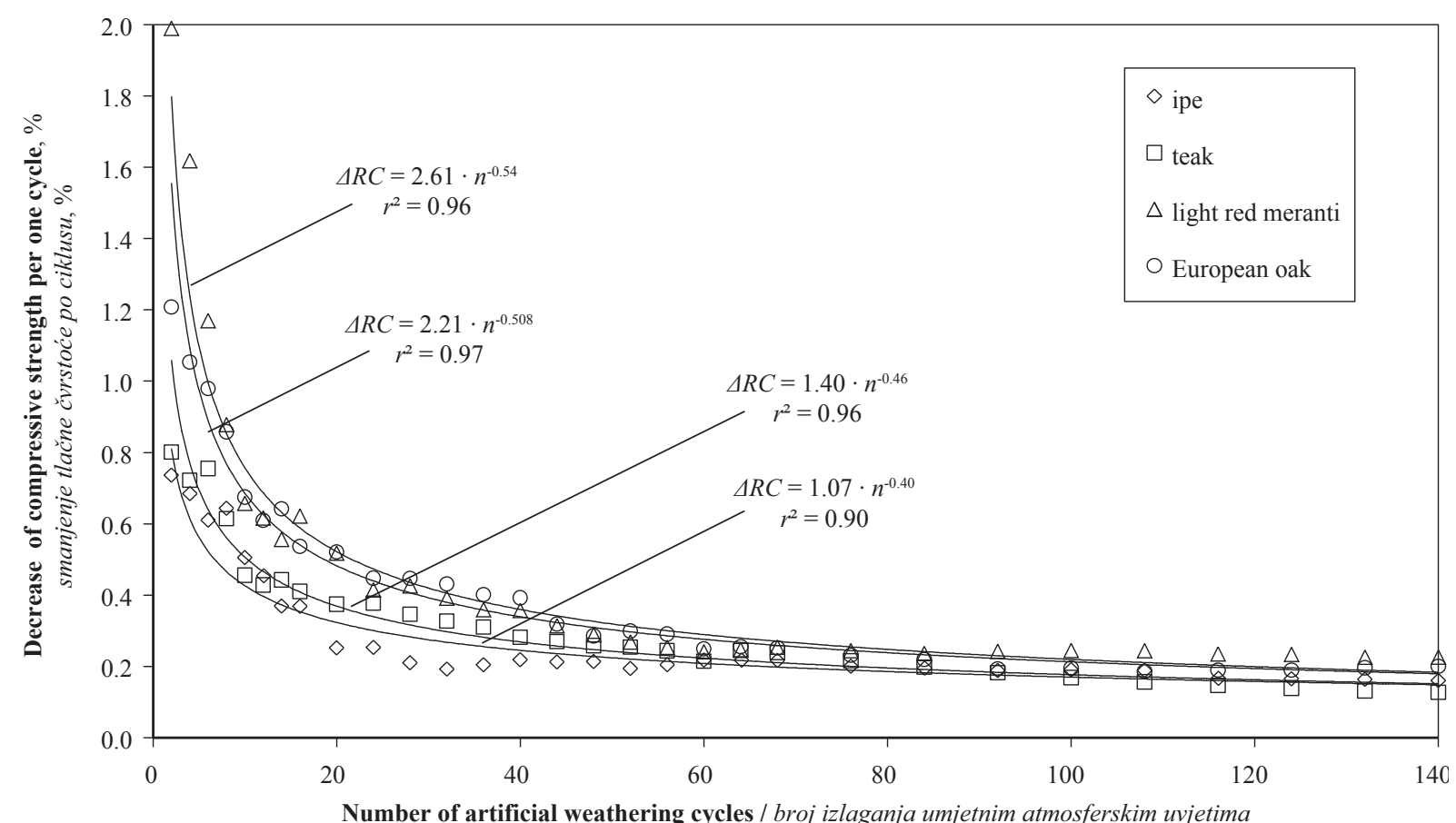

Figure 3 The dependence of decrease of compressive strength along fibers after one cycle of artificial weathering on the number cycles of artificial weathering for light red meranti, ipe, teak and European oak

Slika 3. Ovisnost smanjenja tlačne čvrstoće uzduž vlakanaca nakon jednog ciklusa izlaganja umjetnim atmosferskim uvjetima o broju ciklusa izlaganja drva svjetlocrvenog merantija, ipe, tika i europskog hrasta umjetnim atmosferskim uvjetima

structure is the reduction of the compression strength from $107 \mathrm{MPa}$ to $78 \mathrm{MPa}$ (approx. $27 \%$ ). The loss of compressive strength of other wood species ranged between 22 and $32 \%$, and without taking into account the extreme case of teak wood, the volume change decreases with the increase of wood density.

Irrespective of wood species, the results of testing compressive strength along fibers at different stages of artificial weathering process can be described by a straight line (a correlation coefficient above 0.91 in all cases) - Table 2. Regression analysis shows that the higher the density of wood is, the slope (gradient) value $(a)$ decreases and the value of constatnt term $(b)$ increases.

To illustrate the effect of artificial weathering of tested wood species, the approximate percent loss of the compressive strength along fibers per one cycle of aging $(\Delta R C)$ was determined. Irrespective of wood species, the character of changes was similar. Because of this, a few examples of the calculation of results are presented in Figure 3. The first cycles of artificial weathering process have the greatest influence on the loss of compressive strength. It could be due to the fact that the initial rapid changes in wood moisture caused the strongest stress sorption. As the number of conducted cycles of artificial aging rises, the loss of strength for one aging cycle is getting smaller and tends to a constant value (from about $45-50$ cycles of the artificial aging process). Thus, the progressive aging changes in the strength of wood proceed more slowly.

\section{CONLUSION}

\section{ZAKLJUČAK}

The presented results showed that the process of artificial weathering causes a reduction of the compressive strength along fibers of all tested wood species. The
Table 2 List of parameters of the equation $\left(R C_{n}=a \cdot R C_{0}+b\right)$ describing the change of compressive strength along fibers during artificial weathering

Tablica 2. Parametri jednadžbe $\left(R C_{n}=a \cdot R C_{0}+b\right)$ kojom se opisuju promjene tlačne čvrstoće uzduž vlakanaca tijekom izlaganja promatranih vrsta drva umjetnim atmosferskim uvjetima

\begin{tabular}{|l|c|c|c|c|}
\hline \multirow{2}{*}{$\begin{array}{l}\text { Wood species } \\
\text { Vrsta drva }\end{array}$} & $R C_{0}$ & \multicolumn{3}{|c|}{$\begin{array}{c}\text { Regression analysis } \\
\text { Regresijska analiza }\end{array}$} \\
\cline { 2 - 5 } & $\mathrm{MPa}$ & $a^{*}$ & $b^{*}$ & $r^{*}$ \\
\hline western red cedar & 35.50 & -0.047 & 33.048 & -0.93 \\
\hline gaboon & 43.30 & -0.042 & 40.388 & -0.98 \\
\hline light red meranti & 48.07 & -0.091 & 45.677 & -0.98 \\
\hline Scots pine (sapwood) & 58.25 & -0.102 & 55.889 & -0.98 \\
\hline Scots pine (heartwood) & 60.04 & -0.103 & 57.920 & -0.97 \\
\hline merbau & 64.58 & -0.120 & 60.070 & -0.96 \\
\hline iroko & 62.07 & -0.096 & 60.220 & -0.96 \\
\hline teak & 58.10 & -0.068 & 55.203 & -0.91 \\
\hline European oak & 46.12 & -0.070 & 43.379 & -0.95 \\
\hline garapa & 67.77 & -0.135 & 64.449 & -0.98 \\
\hline opepe & 74.17 & -0.124 & 70.385 & -0.96 \\
\hline afzelia & 70.06 & -0.127 & 65.347 & -0.95 \\
\hline angelim pedra & 71.06 & -0.102 & 69.476 & -0.98 \\
\hline eucalyptus & 70.57 & -0.125 & 67.657 & -0.98 \\
\hline tatajuba & 74.46 & -0.110 & 69.373 & -0.91 \\
\hline ipe & 85.71 & -0.132 & 83.472 & -0.98 \\
\hline balau & 97.15 & -0.133 & 93.562 & -0.97 \\
\hline courbaril & 101.22 & -0.143 & 97.349 & -0.97 \\
\hline cumaru & 107.72 & -0.191 & 102.350 & -0.95 \\
\hline massaranduba & 92.43 & -0.113 & 91.176 & -0.98 \\
\hline
\end{tabular}

* $a$-slope / nagib , $b$ - constant term / konstanta,$r$ - correlation coefficient / koeficijent korelacije

loss of the strength of wood was greater if wood was subjected to more artificial weathering cycles. Hydrophobic teak showed the greatest resistance to artificial 
weathering factors, expressed through the smallest decrease in the compressive strength along fibers. It is followed by massaranduba (the heaviest wood in the group). while gaboon and merbau showed the lowest resistance (loss of strength was partly the result of irregular arrangement of fibres). European wood species (oak and Scots pine) showed greater resistance to weathering factors as wood of similar density but of interlocked fibres.

At later stages of artificial weathering, the loss of compressive strength along fibers, after one cycle of artificial weathering. gets smaller and tends to a constant value - the highest intensity of change takes place at the beginning of the artificial weathering process. The rate (intensity) of changes depends on the initial density of wood.

\section{REFERENCES}

\section{LITERATURA}

1. Bhat, I. H.; Khail, H. P. S. A.; Awang, H. B.; Bakare, I. O.; Issam, A. M., 2010: Effect of weathering on physical, mechanical and morphological properties of chemically modified wood materials. Materials and Design, 31: 4363-4368 ttp://dx.doi.org/10.1016/j.matdes.2010.03.045

2. Colom, X.; Carrillo, F.; Nogues, F.; Garriga, P., 2003: Structural analysis of photodegraded wood by means of FTIR spectroscopy. Polymer Degradation and Stability, 80: $543-549$

http://dx.doi.org/10.1016/S0141-3910(03)00051-X.

3. Evans, P. D.; Urban, Ć. K.; Chowdhury, M. J. A., 2008: Surface checking of wood is increased by photodegradation caused by ultrafiolet and visible light. Wood Science and Technology, 42: 251-265

http://dx.doi.org/10.1007/s00226-007-0175-0.

4. Evans, P. D.; Thay, P. D.; Schmalzl, K. J., 1996: Degradation of wood surfaces during natural weathering. Effects on lignin and cellulose and on the adhesion of acrylic latex primers. Wood Science and Technology, 30: 411-422 http://dx.doi.org/10.1007/BF00244437

5. Feist, W. C., 1983: Weathering and Protection of Wood. American Wood Preservers' Association: 195-205.

6. Feist, W. C., 1988: Weathering of wood and its control by water-reppellent preservatives. In M. P. Hamel (ed.): Wood protection Techniques and the use of Treated Wood in Construction (Madison. WI: Proc. 47358. FPRS): 77-81.

7. Feist, W. C., 1990: Outdoor Wood Weathering and Protection. In: Rowell, R. M.; Barbour, R. J. eds. Archaeological wood: properties, chemistry, and preservation. Advances in Chemistry Series 225. Proceedings of 196th meeting of the American Chemical Society; 1988 September 25-28; Los Angeles, Washington, DC: American Chemical Society. Chapter 11: 263-298.

8. Feist, W. C.; Hon, D. N. S., 1984: Chemistry of weathering and protection. In: Rowell, R. M.; Barbour, R. J. (eds.): The chemistry of solid wood. Advances in Chemistry Series 207, Washington, DC: American Chemical Society, Chapter 11: 401-451

http://dx.doi.org/10.1021/ba-1984-0207.ch011.

9. Follrich, J.; Teischinger, A.; Müller, U., 2011: Artificial ageing of softwood joints and its effect on internal bond strenght with special consideration of flat-to-end grain joints. European Journal of Wood and Wood Product Vol. 69: 597-604 http://dx.doi.org/10.1007/s00107-010-0511-1

10. Grabner, M.; Müller, U.; Gierlinger, N.; Wimmer, R., 2005: Effects of heartwood extractives on mechanical properties of larch. IAWA Journal, 26 (2): 211-220 http://dx.doi.org/10.1163/22941932-90000113.
11. Holz, A., 1981: Zum Alterungsverhalten des Werkstoffes Holz - einige Ansichten, Untersuchungen, Ergebnisse. Holztechnologie, 22/2: 80-85.

12. Hon, D. N. S.; Clemson, S. C.; Feist, W. C., 1986: Weathering characteristics of hardwood surfaces. Wood Science and Technology, 20: 169-183.

13. Kilic, A.; Niemz, P., 2012: Extractives in some tropical woods. European Journal of Wood and Wood Products, 70: 79-83 http://dx.doi.org/10.1007/s00107-010-0489-8.

14. Kollmann, F.; Côte, W. A., 1968: Principles of wood science and wood technology. Solid wood - part I, Springer Verlag, Berlin, Heidelberg, New York http://dx.doi.org/10.1007/978-3-642-87928-9.

15. Matejak, M.; Popowska, E.; Szejka, E., 1983: Vergleichende Untersuchungen über Methoden des beschleunigten Alterns von Holz, Holzforschung und Holzvermertung. Heft, 5:117-119.

16. Miklečić, J.; Jirouš-Rajković, V., 2011: Accelerated weathering of coated and uncoated beech wood modified with citric acid. Drvna industrija, 62 (4): 277-282 http://dx.doi.org/10.5552/drind.2011.1116.

17. Oltean, L.; Teischinger, A.; Hansmann, C., 2009: Wood surface discolouration due to simulated indoor sunlight exposure. Holz Roh- und Wekstoff, 66: 51-66 http://dx.doi.org/10.1007/s00107-007-0201-9.

18. Oltean, L.; Hansmann, C.; Nemeth, R.; Teischinger, A., 2010: Wood surface discolouration of three Hungarian hardwood species due to simulated indoor sunlight exposure. Wood Research, 55(1): 49-58.

19. Pastore, T. C. M.; Santos, K. O.; Rubim, J., 2004: A spestrocolorimetric study on effect on ultraviolet irradiation of four tropical hardwoods. Biosource Technology, 93: 37-42 http://dx.doi.org/10.1016/j.biortech.2003.10.035.

20. Schnabel, T.; Zimmer, B.; Petutschinigg, A. J., 2009: On the modeling of colour changes of wood surfaces. European Journal of Wood and Wood Products, 67: 141-149 http://dx.doi.org/10.1007/s00107-008-0293-x.

21. Temiz, A.; Terziev, N.; Eikenes, M.; Hafren, J., 2007: Effect of accelerated weathering of surface chemistry modified wood. Applied Surface Science, 253: 5355-5362 http://dx.doi.org/10.1016/j.apsusc.2006.12.005.

22. Tolvaj, L.; Faix, O., 1995: Artificial ageing of wood monitored by DRIFT spectroscopy and CIE L* a* $b^{*}$ color measurements. 1. Effect of UV light. Holzforschung - International Journal of the Biology, Chemistry, Physics and Technology of Wood, 49(5): 397-404.

23. Williams, R. S., 1999: Finishing of Wood. In: Wood handbook - Wood as engineering material. Gen. Tech. Rep. FPL-GTR-113, Madison, WI: U.S. Department of Agriculture, Forest Service, Forest Product Laboratory.

24. Williams, R. S., 2005: Weathering of wood. Handbook of wood chemistry and wood composites. Boca Raton: CRC Press: $139-185$.

25. *** PN-D 04102 (1979) Drewno. Oznaczenie wytrzymałości na ściskanie wzdłuż włókien.

26. *** PN-EN 13556 (2005) Drewno okrągłe i tarcica. Terminologia stosowana w handlu drewnem w Europie.

\section{Corresponding address:}

Assist. prof. AGNIESZKA JANKOWSKA Ph.D.

Department of Wood Sciences and Wood Protection

Faculty of Wood Technology

Warsaw University of Life Sciences - SGGW

Nowoursynowska 159 St.

02-776 Warsaw, POLAND

e-mail: agnieszka_jankowska@sggw.pl 